\title{
Comets and Epidemics before the Advance of Newtonian Physics
}

\author{
Espinosa Sánchez JM* \\ University of Quintana Roo, Mexico
}

*Corresponding author: Juan Manuel Espinosa Sánchez, University of Quintana Roo, México, Tel: (983) 8350300; Email: newtonopticks@yahoo.com.mx

\section{Research article}

Volume 3 Issue 2

Received Date: May 01, 2020

Published Date: June 09, 2020

DOI: $10.23880 /$ phij-16000145

\section{Abstract}

The present paper aims to analyze the methodological differences between the Catholic religion and Isaac Newton, to explain what is a comet? In the last third of the 17th century, in England, a radical change occurred around physics. Scientists devoted themselves to studying the cosmos with methods based on experimentation and observation, with new mathematics. Newton also wrote the Mathematical Principles of Natural Philosophy that in the third book dedicated to the Solar System deals scientifically with comets.

To this end, we will put two examples: the comets of 1736 and 1758, where epidemics, wars and deaths of kings appeared, which bodes ill for society at that time because economic crises, deaths, hunger come, the church related the comet that appeared in Heaven as the wrath of God against humanity for their sins. While Newtonian optics analyzed it with science with the gravitational theory whose scientific achievement was demonstrated with the most advanced mathematics.

Keyword: Comet; Newton; Newtonian optics; Principia and Halley

\section{Introduction}

In 1679 Isaac Newton was appointed secretary of the Royal Society, and on April 28, 1686 he presented the draft of the Principia there for publication. In 1687 it was printed, and soon it was sold out. In the Principia, Newton enunciated the gravitational theory and explained the Solar System, in addition to its axioms of motion; also explained the movement of the moon and the free fall of the bodies, among other phenomena analyzed with the most advanced mathematics of its time.

According to Newton, the Sun was the center of the Solar System, and the largest member of that system, and due to its force of gravity, the planets known in the 17th century revolved around it, with elliptical orbits: Mercury, Venus, Earth, Mars, Jupiter, and Saturn [1] (pp. 8-15 and 194), [2] (pp: 45-76). Comets revolve around the Sun in elliptical orbits, such as Halley, Encke, Borelly, Oterma, and Crommelin. But there are also comets, like the one from 1680, which are attracted by the gravity of the solar star and draw curved lines, like a parabola. These celestial bodies are seen only once on Earth [3] (pp: 68-75) [4] (pp: 447-448).

In New Spain, Carlos de Sigüenza y Sigüenza explains that the comet of 1680 was a natural phenomenon that had nothing to do with plagues, wars and other evils of human life. Sigüenza also mentions that comets are made of stellar matter [5] (pp: 149); [6] (pp: 9,67). Ioannis Kepler explains that comets are made of stellar matter [7] (pp: 120 and 137), but Galileo was unaware of the matter that makes up a comet [8] (pp: 155) [9] (pp: 28). The appearance of a comet in the sky was a harbinger of disease, epidemics, war, and the death of kings [10] (pp: 193). In the case of New Spain, the following works by Rubial can be consulted [11] (pp: 148149; 1998: 47-48, 64, 103 and 155) [12] (pp: 173, 270). In ancient times, in the Christian religion, extraordinary natural phenomena were seen as divine punishment for human sins [13] (pp: 116-118, 125, 137, 143, 148, 162-163,169).

\section{The Comet of 1736 and the Matlazahuatl Epidemic}

A comet appeared in the Earth's sky in October 1736, 


\section{Philosophy International Journal}

the English astronomer William Whiston calculated that the meteorite would collide with Earth and cause the end of the world [14] (pp: 71). The curious thing that on July 1, 1736 the Ottoman Sultan Ahmed III. While in New Spain in the 18th century. The most frequent disease from 1736 to 1738 was hepatitis and typhoid (matlazahuatl), a new epidemic appeared in the New World. The focus of infection was mainly "stagnant water" from a spring and the banks of rivers, where "organic waste", garbage, dead animals, urine and excrement were dumped by the New Hispanics themselves Molina [15] (pp: 137-145). In those years England was in the Caribbean with its naval fleet making Spanish ships uncomfortable. The English were in Wallis (today Belize), Trinidad and Tobajo, Jamaica and the Cayman Islands.

Most of the New Hispanic population was not careful in their personal hygiene. People contaminated the water and then consumed it along with food, causing serious health problems in the population, such as the aforementioned epidemics. Other causes of the diseases were "misery", "overcrowding in houses" and "coexistence with animals". All of this created an unhealthy atmosphere responsible for numerous deaths [16] (pp: 99). In addition, some climatic factors (heavy rains, frosts, droughts, etc.) also contributed to the increase in mortality, hunger and agricultural crises [17] (pp: 171-176) [18] (pp: 190-191).

In 1736 a comet appeared in the New Spanish firmament, and in 1737 a solar eclipse occurred, celestial phenomena that were incorporated by ecclesiastical authorities into the causes of the appearance of the matlazahuatl epidemic, and was interpreted as divine punishment against the population of the New Spain [19] (pp: 194-201) [20] (pp: 24). Pescador [21] (pp: 276-283) mentions that on the night of September 7,1736 there was an earthquake that shook Mexico City, and in that year the matlazahuatl appeared. Valle can be consulted about the mentioned natural phenomenon [22] (pp: 7, 116119). Ferrer [23] (pp: 188-189 and 192) mentions that the eclipses of the Sun and the Moon cause diseases, accidents, droughts, rains, wars and fires, and that they are harmful to "women pregnant". During the matlazahuatl epidemic (hepatitis and typhoid) between 1736-1738, New Spanish society demonstrated its devotion to the Virgin of Guadalupe to seek help and divine comfort against this deadly disease that had no cure [24] (pp: 18) [25] (pp: 4) [26] (pp: 281).

\section{Halley's Comet of 1758 and the Smallpox and Measles Epidemics}

By the 18th century, astronomy was not yet so developed in cometary studies, the final touch was missing for the triumph of Newtonian science and it will be when Halley's comet appears in the sky.
Only the Catholic religious philosophical system was affected in the explanation of the scientific conception of the world, by means of a science different and distant from religion, this rational science (Newtonian), comes from Great Britain in the last third of the 17th century and It will last throughout the eighteenth century, with different postulates to face the hegemony of the Catholic Church in knowledge [27] (pp: 43). Newtonian science will figure out what a comet is.

The matter that constitutes a comet is ice and they are attracted by the gravitational force of the Sun, it also has different directions, like Halley's Comet, whose orbit is an eccentric ellipse and has a period of 75 years to be observed from Earth, or otherwise the 1680 comet, which had a parabolic line and could only be seen once by astronomers from different regions of our planet [28] (pp: 371-375).

So there is a "development of knowledge" with effectiveness in solving problems of natural phenomena, which led to the appearance of a comet in the sky at the time, which was not a product of God's punishment, for the sins or bad behavior of men and women by breaking the morals of the Catholic religion.

As a man of science, Newton studied comets, in addition to integrating these meteorites into the Solar System, granting them eccentric orbits, and considered them as a "celestial body illuminated by the Sun". In this regard Newton in his great work the Principia, in book III, Proposition XLII, entitled: "Correct the found path of a comet."

"(...) the periodic time of a comet that rotates in any orbit, and then the transverse sides of the elliptical orbits will be known (...) (like the comet) that appeared in the year 1607 (...) very closely agrees with this orbit with the orbit of the comet that appeared in 1682. If these two comets were one and the same, this comet would rotate over a period of 75 years the comet would return again through the same elliptical orbit).

(In addition there are other comets that have) varied movements (hyperbola and parabola) are directed towards all regions of the sky. (As it was) the comet that appeared in the year 1680 (...) " [28] (pp: 371-374) 1 .

1 Spanish to English translation:“(...) el tiempo periódico de un cometa que gira en una órbita cualquiera, y se conocerán entonces los lados transversales de las órbitas elípticas (...) (como el cometa) que apareció el año de 1607 (...) concuerda muy aproximadamente esta órbita con la órbita del cometa que apareció en 1682. Si estos dos cometas fueran uno y el mismo, este cometa giraría en un período de 75 años el cometa regresara de nuevo por la misma órbita elíptica).

(Además hay otros cometas que tienen) movimientos variados (hipérbola y parábola) se dirijan hacia todas las regiones del cielo. (Como fue) el cometa que apareció el año 1680 (...)”(Newton, 2002: 371-374). 


\section{Philosophy International Journal}

Halley's Comet named after French astronomers appeared in 1758, causing Newtonian physics to triumph against the religious ideas of the time that saw these celestial phenomena as something proper to God to terrify and punish humanity for their sins on Earth.

In that year smallpox appeared in America in Santa Fe de Bogotá [29] and measles in Scotland (Edinburgh) with a high mortality rate in the population [30] (pp: 1845: 413). With the Seven Years' War between 1753-1763, and in the years from 1758 to 1759, the war is in North America in Canada with heavy fighting between the English and the French. In 1758, Bárbara de Braganza, queen of Spain, died, and the following year, Fernando VI, king of Spain.

Despite these problems that the world had of wars, epidemics and the death of kings, Newtonian science kept going and Newton after death his postulates were correct in the explanations of comets in the Solar System.

Furthermore, in the Principia there is an idea that every particle of matter in the universe attracts every other with a force directly proportional to the product of its masses and inversely proportional to the square of its distances between its centers. Talk about mass equation and distance [31](pp: 754).

For our studies we are interested in the explanations that Newton gives in his respective mentioned work on comets, which are: "Bodies that move practically in large circles when their speed decreases [...] the great approximation of comets is also confirmed by light from their heads, since the light of a celestial body that illuminated by the Sun moves away to remote parts [...] Consequently, given the amount of light and the apparent diameter of a comet at a distance from a planet directly as its diameters and conversely as the square root of its light (the comet of 1680 mentions us), [...] it moved with its maximum speed so it was in its perigee, but the maximum splendor of their heads was observed two weeks before, when they finished away from the sun's rays, and the maximum splendor of their tails was observed a little earlier, when it was even closer to the Sun [...] Consequently, comets shine in the sunlight that $r$ efleja [...] comets follow oblique paths and, sometimes contrary to the course of the planets, they move in all directions with the greatest freedom and retain their movements for an extremely long time, even when they are contrary to the course of the planets [...] given that the heads are surrounded by immense atmospheres, the lowest parts of which must be the densest, so it is not in the bodies of the comets themselves, but only in the clouds, where these changes are seen [...] ". [31] (pp: 762-764)2.

2 Spanish to English translation: “Cuerpos que se mueven prácticamente

\section{Newton Later Tells Us:}

"That comets move in some of their conical sections, with foci in the center of the Sun, and that, by means of rays traced to the Sun, they describe areas proportional to the times [...] But their orbits will resemble parabolas so much that for them they can use parables without possible error [...]" [31](pp: 764-765) ${ }^{3}$.

Newton with the help of Edmund Halley makes comparisons of the 1680 comet, from the observations of Flamstead who was the first Royal astronomer of England, who observed the mentioned comet in London [32] (pp: 2446).

\section{Conclusion}

Isaac Newton, as he is known, destroys with the tautological definitions of the movement of the stars. With the support of Edmund Halley, they studied the movement of comets, giving as an example that of 1680 , which determined a parabolic trajectory, and that of 1682 , gives it an elliptical movement. Reaching the parabola motion of a comet that appears only once in the Solar System, with the motion of the elliptical, the comet will have periods of appearing in tone to the Sun. These are important scientific advances in understanding the cosmos, which exposes Newton in his Principia also believes in a Divine being. The comet of 1680 was studied in America, where Sigüenza is the only scientist who tries to calculate its parallax through demonstration by means of trigonometry.

With the predictions of the period Newton assigned to

en grandes círculos cuando su velocidad disminuye [...] la gran aproximación de los cometas se confirma también por la luz de sus cabezas, pues la luz de un cuerpo celeste que iluminado por el Sol se aleja hacia partes remotas [...] En consecuencia, dada la cantidad de luz y el diámetro aparente de un cometa a la distancia de un planeta directamente como sus diámetros e inversamente como la raíz cuadrada de su luz (nos menciona el cometa de 1680), [...] se movía con su máxima velocidad por lo que se encontraba en sus perigeos, pero el esplendor máximo de sus cabezas se observó dos semanas antes, cuando acababan de apartarse de los rayos solares, y el esplendor máximo de sus colas se observó un poco antes, cuando estaba aún más cerca del Sol [...] En consecuencia, los cometas brillan por la luz del Sol que refleja [...] los cometas siguen trayectorias oblicuas y, a veces contrarías al curso de los planetas, se mueven en todas direcciones con la mayor libertad y conservar sus movimientos durante un tiempo extremadamente prolongado, incluso cuando son contrarios al curso de los planetas [...] dado que las cabezas están rodeadas por inmensas atmósferas, cuyas partes más bajas deben ser las más densas, por lo que no es en los cuerpos de los cometas mismos, sino sólo en las nubes, donde se ven dichos cambios [...]". (Newton, 1982: 762-764).

3 Spanish to English translation: Que los cometas se mueven en algunas de sus secciones cónicas, con focos en el centro del Sol, y que, mediante radios trazados al Sol, describen áreas proporcionales a los tiempos [...] Pero sus órbitas se asemejarán tanto a parábolas que para ellos pueden utilizar parábolas sin error posible [...]. (Newton, 1982: 764-765). 


\section{Philosophy International Journal}

the comet of 1682, the world's scientists waited for the year 1758. French astronomers named it Halley's Comet, when it appeared in the sky and with it the triumph of Newtonian celestial mechanics was seen Rewarded as predicted by Newton in 1687 in his Principia, using infinitesimal calculus to demonstrate its elliptical motion, the comet will have periods of appearing around the Sun.

\section{Bibliography}

1. Sagan C, Jonathan NL (1974) Los planetas. México. Lito Offset Latina.

2. Sagan C (1992) Cosmos. México, Planeta.

3. Sagan C, Ann D (1986) El Cometa. España, Planeta.

4. Amedée G (1875) Les comètes, París, Librairie Hachette.

5. Sigüenza y Góngora C (1984) La libra astronómica y filosófica. $2^{\text {nd }}(E d n)$, México, IIFs-UNAM.

6. Trabulse E (1974) Ciencia y religión en el siglo XVII. México, El Colegio de México.

7. Kepler I (1984) El mensaje y el mensajero sideral. Madrid, Alianza.

8. Galilei G (1984) El ensayador. Madrid, Sarpe.

9. Kino EF (1681) Exposición astronómica del cometa que el año de 1680, por los meses de noviembre y diciembre y este año de 1681, por los meses de enero y febrero se ha visto en todo el mundo y se le ha observado en la ciudad de Cádiz, México, Imprenta de Francisco Rodríguez Lupercio.

10. Ptolomy C (1980) Tetrabiblos. Londres, William Heinemann LTD, (The Classical Library: 435).

11. Rubial García A (1996) Los libros del deseo. México, CONACULTA-Ediciones del Equilibrista.

12. Rubial García A (1999) La santidad controvertida. México, FCE-UNAM.

13. Eliade M (2001) El mito del eterno retorno. Argentina, Emecé.

14. Modeen M (2009) God \& Other Metaphors.

15. Molina del Villar A (2001) La Nueva España y el Matlazahuatl 1736-1739. México, CIESAS-Colegio de Michoacán.

16. Cuenya CM, Miguel A (1994) Epidemias y Salubridad en la Puebla de los Ángeles (1675-1833). In: Rosalva L, Francisco J, Cervantes B (Eds.), Limpiar y Observar. La basura, el agua y la muerte en la Puebla de los Ángeles. 1650-1925, México, Claves Latinoamericana-Colegio de Puebla, pp: 69-125.

17. Malvido E (1992 ${ }^{a}$ ) Cronología de epidemias y crisis agrícolas en la época colonial", ). In: Enrique F, Elsa M (Eds.), Ensayos sobre la historia de las epidemias en México, tomo I, México, IMSS, pp: 171-176.3

18. Malvido E (1992b) Efectos de las epidemias y hambrunas en la población colonial de México (1519-1810). In: Enrique Florescano \& Elsa Malvido (compiladores), Ensayos sobre la historia de las epidemias en México, tomo I, México, IMSS, pp: 179-197.

19. Brading DA (2002) La Virgen de Guadalupe. Imagen y tradición. México, Taurus.

20. Campa Mendoza V (2002) Santuarios y milagros, Durango, México. Consejo Nacional de Ciencia y Tecnología del Estado de Durango.

21. Pescador JJ (1992) De bautizos a fieles difuntos. Familia y mentalidades en una parroquia urbana: Santa Catarina de México, 1568-1820. México, El Colegio de México.

22. Valle Béjar MD (2003) Los terremotos en la ciudad de México durante la segunda mitad del siglo XVIII. México, tesis de Maestría en Historia de México, FFL-UNAM.

23. Ferrer Valenciano L (1677) Astronómica curiosa y descripción del mundo superior e inferior. Valencia, España, Imprenta de los Herederos de Gerónimo.

24. Gil Maroño A (1992) Vida Cotidiana y Fiestas en el Veracruz Ilustrado (Siglo XVIII). Tesis de Licenciatura en Historia del Arte, Veracruz, Universidad Cristóbal Cólon.

25. Gil Maroño A (2001) La fiesta como texto: Prácticas culturales y representaciones sociales en la jura de Carlos IV, Veracruz 1790. México, tesis de Maestría en Historiografía de México, UAM-Azcapotzalco.

26. Taylor WB (1996) Magistrates of the Sacred. Priets and Parishioners in Eighteenth-century México, Stanford California, Stanford University.

27. Paine T (2003) La Edad de la Razón. México, CONACULTA.

28. Newton I (2002) Principios Matemáticos de la Filosofía Natural. $2^{\text {nd }}$ (Vol.), Barcelona, RBA.

29. Beltrán M, José L (2020) Historia de las Epidemias: en España y sus Colonias (1348-1919). Madrid, La Esfera de la Vida.

30. Jiménez M (1845) Diccionario de los Diccionarios de 
Medicina. t.VIII, Madrid, Imprenta de Sánchez.

31. Newton I (1982) Principios Matemáticos de la Filosofía Natural. Madrid. Alianza.
32. Espinosa Sánchez JM (2016) La Óptica en la Nueva España y Europa siglos XVII-XVIII. Vita et Tempus 1(1): 24-47. 